\title{
STUDIES ON THE EPIDEMIOLOGY OF SARCOIDOSIS IN THE UNITED STATES: THE RELATIONSHIP TO SOIL AREAS AND TO URBAN-RURAL RESIDENCE
}

\author{
By JOHN T. GENTRY, ${ }^{1}$ HAROLD M. NITOWSKY, ${ }^{2}$ aNd MAX MICHAEL, JR. ${ }^{3}$ \\ (From the Communicable Disease Center, Public Health Service, U. S. Department of Health, \\ Education, and Welfare, Atlanta, Georgia; the Medical Service, Veterans Administration \\ Hospital, Atlanta, Georgia; and The Department of Medicine, Emory University \\ School of Medicine, Atlanta, Ga.)
}

(Submitted for publication October 16, 1953; accepted August 3, 1955)

During World War II, there were 350 recognized cases of sarcoidosis among American Armed Forces personnel. These cases, chosen in a relatively unselected manner, afford an admirable opportunity for investigation into some of the aspects of the epidemiology of this disease. Preliminary studies of this group have demonstrated a striking concentration of patients' birthplaces in the Southeastern United States $(1,2)$. Although cases in negroes predominated, the observed geographic localization could not be accounted for solely by the distribution of the negro population in the United States. The present investigation, which was concerned with factors which might have influenced this unusual case distribution, revealed an association between the distribution of the cases and certain soil areas. Furthermore, a higher incidence of the disease was found among servicemen from the more rural areas of the Southeast. These correlations may serve as additional localizing factors for further studies on the epidemiology of sarcoidosis.

\section{MATERIAL AND METHODS}

Of the 350 cases of sarcoidosis diagnosed in World War II servicemen, there were 334 living at the time of this study. Only these were investigated since the compilation of epidemiologic data would be incomplete in those deceased. In many patients the disease was discovered accidentally by routine $x$-ray examination taken during the course of hospitalization or upon separation from service. The diagnoses of sarcoidosis were made in American military hospitals scattered over the

1 Present address: District State Health Officer, District Office, 400 Foote Bldg., 316 So. Warren St., Syracuse, New York.

2 Present address: Sinai Hospital of Baltimore, Baltimore, Maryland.

3 Present address: Maimonides Hospital of Brooklyn, 4802 Tenth Avenue, Brooklyn 19, New York. world. In all instances the biopsy specimens were reviewed and confirmed by the Armed Forces Institute of Pathology. A record of the induction chest film and physical examination was available on all patients. The complete records of all hospitalizations on each patient were studied and an analysis of the clinical data is in preparation. The standards for verification of the diagnosis have been previously reported $(1,2)$. The present analysis has been restricted to 297 of these cases, 37 were excluded because of the lack of availability of data to clearly establish locale of residence or diagnosis.

The minimum information on these cases consisted of identifying data including race, birthplace, residence at the time of entry into the military service, i.e., "induction residence", and clinical and pathological reports which conformed to the criteria for the diagnosis of the disease, as proposed by the National Research Council (1). Additional consideration was given to those cases whose birthplace and induction residence were in the same or adjacent counties. For convenience, these cases have been arbitrarily designated "lifetime residents".

Figures giving the total number of persons serving in all the military services from the beginning of conscription to December 2, 1946, were obtained through the courtesy of the National Selective Service. These data, available by county and state of ind 'ction and race, were used as a basis for calculating race specific attack rates. Since the numerator consists of servicemen, a denominator representing the source of this group would be needed for calculation, hence the use of this Selective Service data. While certain factors of bias, such as omission of females, older persons and those rejected from military duty, are recognized in these rates, this military service information represented the most appropriate denominator that was available. The rates by induction residence, in turn, were selected because factors of migration, particularly the movement of $\mathrm{Ne}$ groes from the Southeast to the northern industrial centers, prolonged the determination of accurate rates by birthplace.

The soil classification data which were used in this study were obtained through the courtesy of the Division of Soil Survey, United States Department of Agriculture. By the use of a recent map, showing the soil regions of the South, the various counties in Alabama, 
Arkansas, Florida, Georgia, Louisiana, Mississippi, North Carolina, South Carolina, and Texas were placed in one of 91 categories, depending upon the predominant soil series charted for each county. The soil series, in turn, were combined into larger groups on the basis of similarities in topography, profile, and parent materials, to form the soil areas characteristic of the Piedmont Plateau, Middle and Lower Coastal Plain, and other physiographic divisions of the Southeast. These soils are contained for the greater part in 8 of the 36 great soil groups thus far recognized in the United States, namely, the Red-Yellow Podzolic soils, Rendzinas. Alluvial soils,

TABLE I

Cases of sarcoidosis in the Armed Forces during World War II, according to states, by race, birthplace, and induction residence

\begin{tabular}{|c|c|c|c|c|c|c|}
\hline \multirow[b]{3}{*}{ State } & \multicolumn{6}{|c|}{ Number of cases } \\
\hline & \multicolumn{3}{|c|}{ Birthplace } & \multicolumn{3}{|c|}{ Induction residence } \\
\hline & Total & White & Negro & Total & White & Negr \\
\hline \multicolumn{7}{|c|}{ Region I (South Atlantic Gulf Coast) } \\
\hline $\begin{array}{l}\text { Alabama } \\
\text { Arkansas } \\
\text { Florida } \\
\text { Georgia } \\
\text { Louisiana } \\
\text { Mississippi } \\
\text { North Carolina } \\
\text { South Carolina } \\
\text { Texas } \\
\text { Virginia }\end{array}$ & $\begin{array}{l}31 \\
13 \\
11 \\
26 \\
13 \\
22 \\
36 \\
30 \\
23 \\
18\end{array}$ & $\begin{array}{l}5 \\
4 \\
1 \\
3 \\
2 \\
3 \\
4 \\
2 \\
4 \\
2\end{array}$ & $\begin{array}{r}26 \\
9 \\
10 \\
23 \\
11 \\
19 \\
32 \\
28 \\
19 \\
16\end{array}$ & $\begin{array}{l}27 \\
14 \\
15 \\
20 \\
12 \\
19 \\
29 \\
15 \\
20 \\
14\end{array}$ & $\begin{array}{l}5 \\
3 \\
3 \\
2 \\
2 \\
4 \\
2 \\
6 \\
2\end{array}$ & $\begin{array}{l}22 \\
11 \\
15 \\
17 \\
10 \\
17 \\
25 \\
13 \\
14 \\
12\end{array}$ \\
\hline Total & 223 & 30 & 193 & 185 & 29 & 156 \\
\hline
\end{tabular}

Region II (Middle Atlantic and Border)

Delaware

District of Columbia

Maryland

New Jersey

New York

Oklahoma

Pennsylvania

Tennessee

West Virginia

Total

Region III (Rest of Country)*

Total

U. S. Total

Arizona
California
Connecticut
Illinois
Indiana
Iowa
Kansas
Kentucky
Massachusetts
Michigan
Missouri
Montana
Nebraska
North Dakota
Ohio
Utah
Washington
Wisconsin \\ Arizona \\ California \\ Illinois \\ Indiana \\ Kansas \\ Kentucky \\ Michigan \\ Missouri \\ North Dakota \\ Washington}

$\begin{array}{rrr}1 & - & 1 \\ -3 & - & - \\ 2 & -2 & - \\ 13 & 12 & 1 \\ 3 & 2 & 1 \\ 3 & 3 & - \\ 8 & 4 & 4 \\ -3 & 2 & 1 \\ -36 & -25 & -11\end{array}$

$\frac{\frac{1}{3}}{\frac{1}{1}}$

$\begin{array}{rrr}1 & - & 1 \\ 6 & - & 6 \\ 4 & - & 4 \\ 7 & 1 & 6 \\ 18 & 15 & 3 \\ 3 & 1 & 2 \\ 14 & 4 & 10 \\ 8 & 3 & 5 \\ 2 & 1 & 1 \\ -\frac{1}{63} & -\frac{25}{38} & -\frac{38}{}\end{array}$

$\begin{array}{rrr}-1 & - & - \\ - & - & - \\ 5 & 3 & - \\ 3 & 3 & - \\ 2 & 2 & - \\ 1 & -1 & - \\ 1 & 1 & - \\ 4 & 4 & 1 \\ 2 & 1 & - \\ 2 & 1 & - \\ 1 & 1 & - \\ 1 & 1 & - \\ 1 & 1 & - \\ 3 & 1 & - \\ 1 & 1 & - \\ 2 & 2 & - \\ 1 & 1 & - \\ -31 & -23 & - \\ 290 \dagger & 78 & 212\end{array}$

212

\begin{tabular}{rrr}
1 & - & 1 \\
6 & 4 & 2 \\
1 & 1 & - \\
8 & 5 & 3 \\
4 & 3 & 1 \\
-2 & - & - \\
1 & 1 & - \\
4 & 1 & - \\
8 & 3 & 5 \\
3 & 2 & - \\
1 & 1 & - \\
1 & 1 & - \\
\hline 6 & -2 & - \\
1 & 1 & - \\
2 & 2 & - \\
- & - & - \\
-49 & -31 & -18 \\
297 & 84 & 212
\end{tabular}

* No cases were recognized from 11 states: Colorado, Idaho, Maine, Minnesota, Nevada, New Hampshire, Oregon, Rhode Island, South Dakota, Vermont, Wyoming.

† Seven white cases were foreign born. 
TABLE II

Sarcoidosis attack rates among World War II servicemen, by race and induction residence, according to regions of the United States

\begin{tabular}{|c|c|c|c|c|c|c|c|c|c|c|}
\hline & \multicolumn{3}{|c|}{ Selective service population } & \multicolumn{3}{|c|}{$\begin{array}{l}\text { Sarcoidosis cases by } \\
\text { induction residence }\end{array}$} & \multicolumn{3}{|c|}{$\begin{array}{l}\text { Attack rates } \\
\text { per } 100,000\end{array}$} & \multirow{2}{*}{$\begin{array}{l}\text { Ratio } \\
\mathrm{N} / \mathrm{W}\end{array}$} \\
\hline & Total & White & Negro & Total & White & Negro & Total & White & Negro & \\
\hline Region I & $2,955,135$ & $2,291,056$ & 664,079 & 185 & 29 & 156 & 6.3 & 1.3 & 23.5 & $18 / 1$ \\
\hline \multicolumn{11}{|c|}{ (South Atlantic Gulf Coast) } \\
\hline $\begin{array}{l}\text { Region II } \\
\text { (Middle Atlanti }\end{array}$ & $\begin{array}{l}4,238,992 \\
\text { c Border) }\end{array}$ & $3,953,837$ & 285,155 & 63 & 25 & 38 & 1.5 & 0.6 & 13.3 & $22 / 1$ \\
\hline $\begin{array}{l}\text { Region III } \\
\qquad \text { (Rest of U. S.) }\end{array}$ & $7,037,448$ & $6,820,041$ & 217,407 & 49 & 31 & 18 & 0.7 & 0.5 & 8.3 & $17 / 1$ \\
\hline Total & $14,231,575$ & $13,064,934$ & $1,166,641$ & 297 & 85 & 212 & 2.1 & 0.7 & 18.2 & $26 / 1$ \\
\hline Ratio of Rates: $\underset{R}{R}$ & $\begin{array}{l}\text { egion I/Reg } \\
\text { egion I/Reg }\end{array}$ & $\begin{array}{l}\text { n III } \\
\text { in II }\end{array}$ & & & & & $\begin{array}{l}9 / 1 \\
4 / 1\end{array}$ & $\begin{array}{l}3 / 1 \\
2 / 1\end{array}$ & $\begin{array}{l}3 / 1 \\
2 / 1\end{array}$ & \\
\hline
\end{tabular}

Reddish-Chestnut soils, Ground-Water Podzolic soils, and Lithosols. 4

The urban-rural distribution data which were used in this study were obtained from the 1940 census report. The population characteristics utilized in the urban-rural classification included population density, as defined by population per square mile, and total population. In relation to the negro cases, the population of negro inhabitants of a county classified as rural by the Bureau of Census was used. For this part of the study a total of 185 cases was studied. Each of these patients had entered military service from one of the ten Southeastern states, the area in which the highest incidence of the disease was found. An attempt was made to characterize the county areas of residence as predominantly rural or urban on a relative basis and to consider attack rates among servicemen from county areas of varying urbanrural composition.

\section{RESULTS}

\section{Geographic distribution}

The breakdown of cases by states is shown in Table I. The states have been divided into three geographic areas on the basis of the relative incidence of the disease. Region I, which had the highest incidence of sarcoidosis, was composed of the nine South Atlantic and Gulf Coast states of Alabama, Florida, Georgia, Louisiana, Mississippi, North Carolina, South Carolina, Texas, and Virginia plus Arkansas. In these states there was a total of 223 cases by birthplace, 30 whites and 193

4 The classification and nomenclature of soils used in this study is that of Soils and Men, U. S. Dept. of Agr. Yearbook of Agriculture, 1938, Part IV, pp. 861-1161, with some modifications outlined in the issue of Soil Science and Soil Classification, Vol. 67, No. 2, 1949. negroes; and 185 by induction, 29 whites and 156 negroes. The difference of 37 negroes indicates the migration of this group out of the section. Region II which had the next highest incidence was contiguous to Region I and comprised the District of Columbia, the five Middle Atlantic States of Delaware, Maryland, New Jersey, New York and Pennsylvania, plus Tennessee, West Virginia and Oklahoma. In these states there was a total of 36 cases by birthplace, 25 whites and 11 negroes; and 63 by induction, 25 whites and 38 negroes. The difference of 27 negroes represents the migration into this industrial region. In the remainder of the country, Region III, there were 31 cases by birthplace, 23 whites and 8 negroes; and 49 by induction, 31 whites and 18 negroes.

Attack rates for sarcoidosis, specific for race and induction residence, are summarized in Table II for the three regions. In the South Atlantic Gulf Coast States, Region I, the overall attack rates are 1.3 and 23.5 for whites and negroes, respectively. The overall rate in the Middle Atlantic and Border States, Region II, was 1.5 per $100,000,0.6$ for whites and 13.3 for negroes. In Region III, the remainder of the country, the overall rate was 0.7 per $100,000,0.5$ among whites and 8.3 among negroes. It is apparent from these attack rates that a marked predominance of the disease exists among negro inductees of all regions, with the remarkably consistent negro-towhite ratios of 18 to 1,22 to 1 , and 17 to 1 for Regions I, II, and III, respectively. It is possible, however, that the disproportionately larger num- 
TABLE III

Sarcoidosis attack rates among World War II servicemen, by race and induction residence, according to the states of the South Atlantic Gulf Coast region

\begin{tabular}{|c|c|c|c|c|c|c|c|}
\hline \multirow[b]{2}{*}{ State } & \multicolumn{3}{|c|}{ Selective service population } & \multicolumn{3}{|c|}{ Attack rates per 100,000} & \multirow{2}{*}{$\begin{array}{c}\frac{(O-E)^{2}}{E} \\
\text { (for Negro cases) }\end{array}$} \\
\hline & Total & White & Negro & Total & White & Negro & \\
\hline $\begin{array}{l}\text { Alabama } \\
\text { Arkansas } \\
\text { Florida } \\
\text { Georgia } \\
\text { Louisiana } \\
\text { Mississippi } \\
\text { North Carolina } \\
\text { South Carolina } \\
\text { Texas } \\
\text { Virginia }\end{array}$ & $\begin{array}{l}272,843 \\
189,327 \\
208,787 \\
292,172 \\
242,943 \\
211,667 \\
349,809 \\
179,664 \\
716,250 \\
291,673\end{array}$ & $\begin{array}{l}202,648 \\
156,550 \\
157,599 \\
220,912 \\
170,620 \\
125,592 \\
276,260 \\
125,201 \\
626,258 \\
229,416\end{array}$ & $\begin{array}{l}70,195 \\
32,777 \\
51,188 \\
71,260 \\
72,323 \\
86,075 \\
73,549 \\
54,463 \\
89,992 \\
62,257\end{array}$ & $\begin{array}{l}9.9 \\
7.4 \\
7.2 \\
6.8 \\
4.9 \\
9.0 \\
8.9 \\
8.3 \\
2.8 \\
4.8\end{array}$ & $\begin{array}{l}2.5 \\
1.9 \\
0 \\
1.4 \\
1.2 \\
1.6 \\
1.4 \\
1.6 \\
1.0 \\
0.9\end{array}$ & $\begin{array}{l}31.3 \\
33.6 \\
29.3 \\
23.9 \\
13.8 \\
19.8 \\
34.0 \\
23.9 \\
15.6 \\
19.3\end{array}$ & $\begin{array}{l}1.83 \\
1.41 \\
0.75 \\
0.01 \\
2.88 \\
0.51 \\
3.43 \\
0.00 \\
2.39 \\
0.46\end{array}$ \\
\hline Total & $2,955,135$ & $2,291,056$ & 664,079 & 6.3 & 1.3 & 23.5 & $\begin{array}{rr}X^{2}= & 13.67 \\
>p & >0.10\end{array}$ \\
\hline
\end{tabular}

ber of negro, as compared to white, emigrants from the Southeast may have altered the negro-towhite attack rate ratios for Regions II and III.

In comparing rates between the regions, it can be seen that the overall rate for Region I, 6.3 per
100,000 , is nine times as great as that for Region III, 0.7 per 100,000 . However, a large part of this difference is due to the disproportionate rates between the two races, since a ratio of less than 3 to 1 is observed between the respective

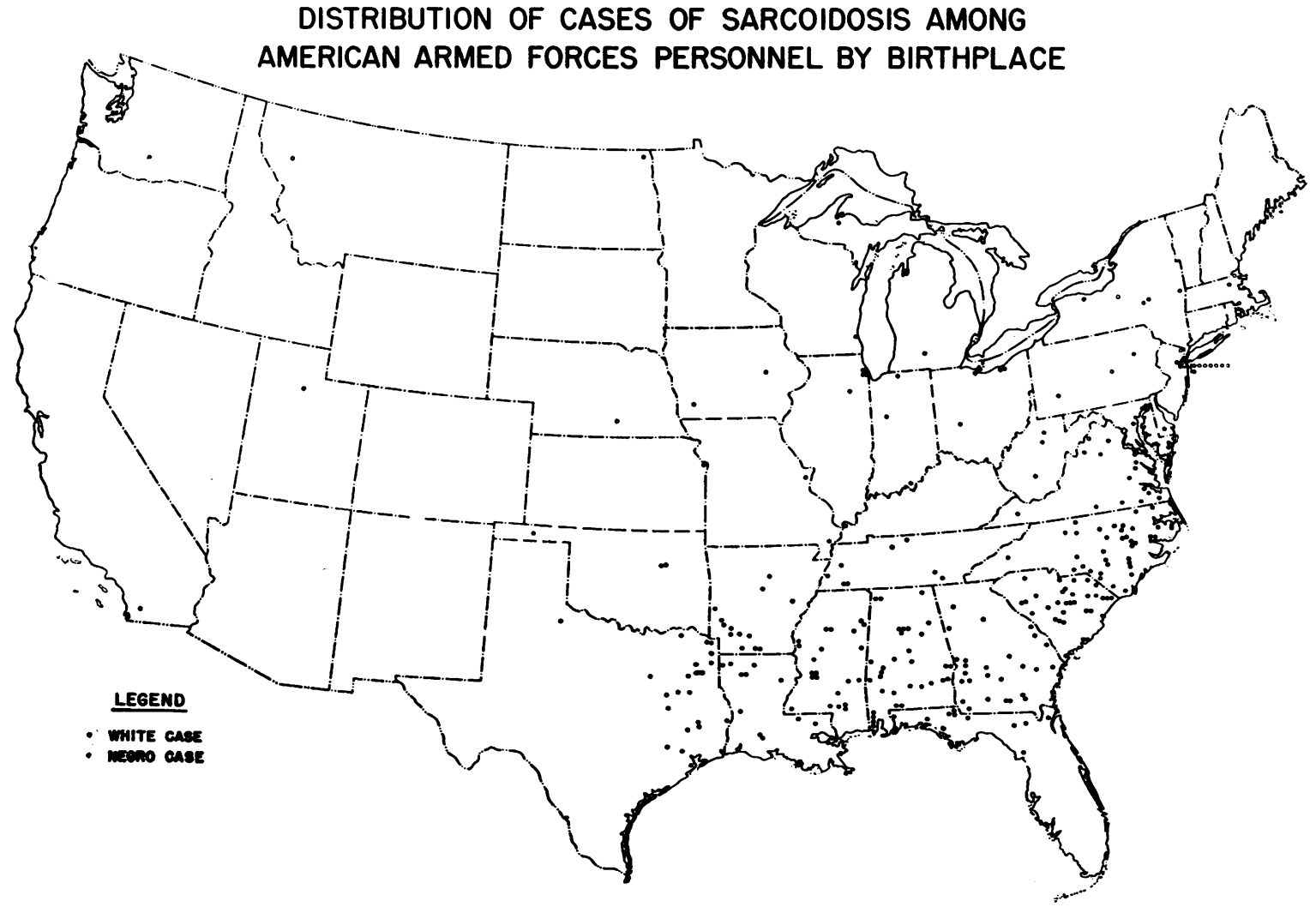

Fig. 1. The Distribution, by Birthplace, of 290 Cases of Sarcoidosis Recognized among World War II SERVICEMEN

Each dot represents the birthplace of a single case. Seven additional cases were foreign-born. 


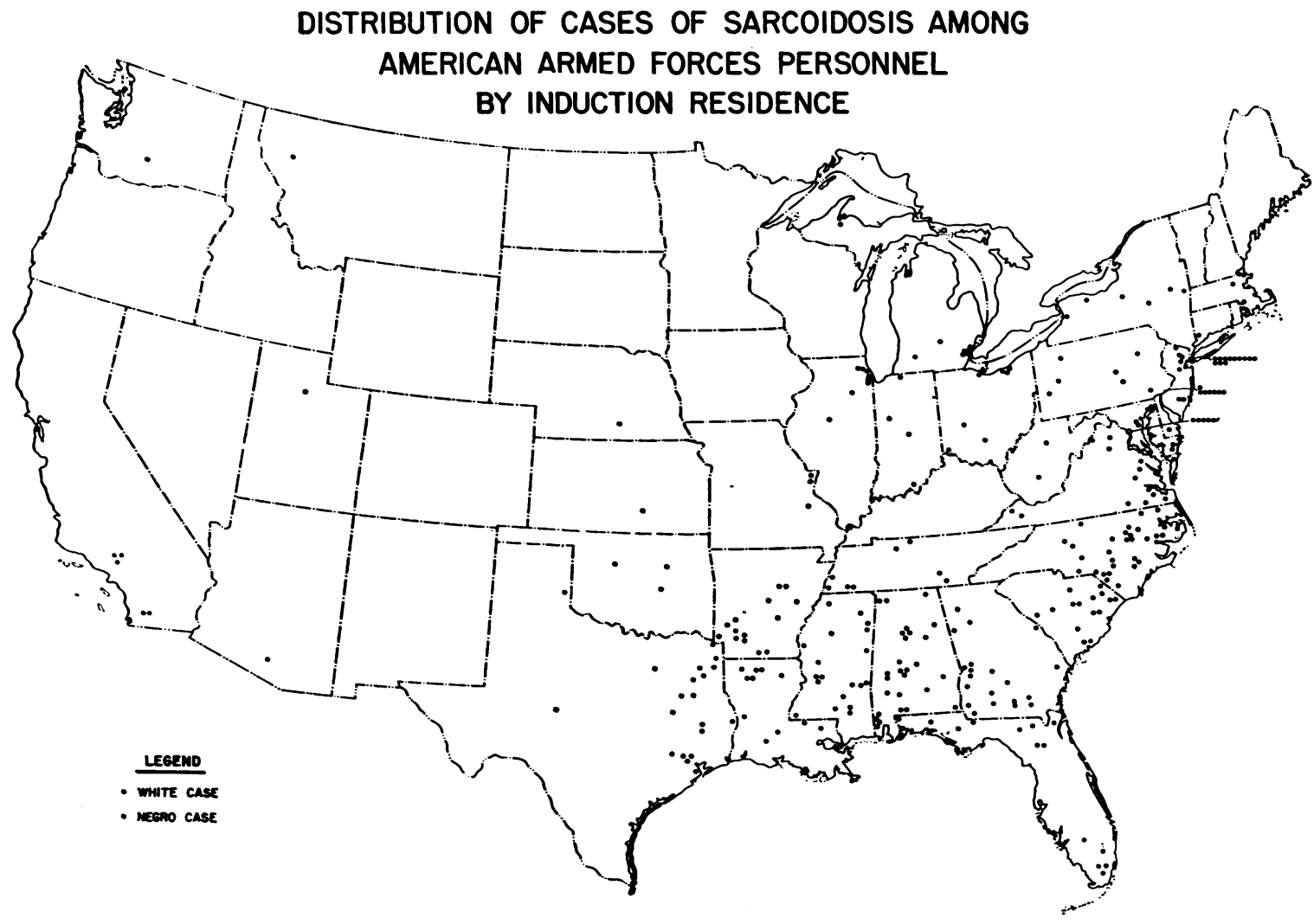

Fig. 2. The Distribution, by Residence at the Time of Induction into the Armed Forces, of 297 Cases of Sarcotdosis Recognized among World War II Servicemen

Each dot represents the induction residence of a single case.

negro and white rates for these regions. Similarly, the 4 to 1 ratio between the overall rates of Regions I and II, 6.3 and 1.5, respectively, also reflects the disproportionate rates between the negroes and whites.

It is evident, therefore, that the higher attack rate for sarcoidosis in the negro and the large negro population in Region I account, in part, for the concentration of cases in this area. However, the 3 to 1 ratio of rates in negroes for $\mathrm{Re}$ gions I and III clearly indicates the presence of some localizing factor, aside from race, which influences the distribution of the cases.

In attempting to disclose what this factor (or factors) might be, subsequent considerations were focused on the ten states of Region I. Attack rates specific for race and induction residence were first determined for each of these states, as shown in Table III. Because of the small number of white cases, comparisons were made between the negroes only. In the table, the observed inci- dence of the disease among negro inductees for each state has been compared with the expected incidence on the basis of the overall rates for the area. It is evident that the variations obtained are not great. Although the negro attack rate for North Carolina, 34.0 per 100,000 , is somewhat greater than that for the rest of the area, 22.2 per 100,000 , this difference is only of questionable statistical significance. Thus, when comparing individual states as units in this manner, it is apparent that no definite concentration of the cases by induction residence exists in any one state.

\section{Relation of the disease to the fall line}

Reference to Figures 1 and 2 will reveal certain peculiarities in the distribution of the cases in the Southeast, both by birthplace and induction residence. Within the Carolinas, a greater number of residences appear in the eastern portion of the states. Concentrations also appear in Southern 


\section{DISTRIBUTION OF SARCOIDOSIS IN IO SOUTHEASTERN STATES BY INDUCTION RESIDENCE in RELATION TO THE "MODIFIED" FALL LINE AREA}

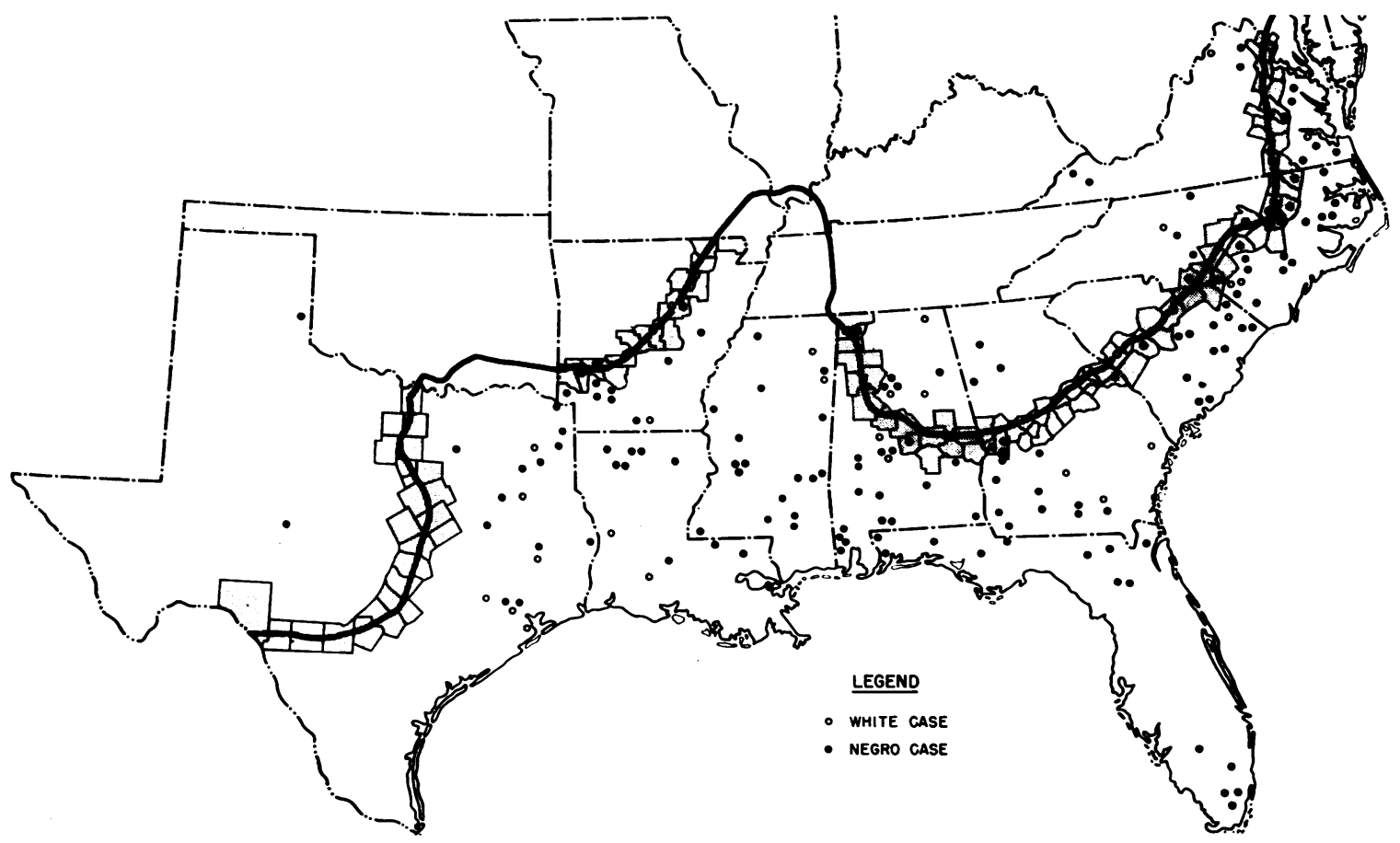

Fig. 3. The Distribution, by Induction Residence, of 185 Cases of Sarcoidosis in the 10 South Atlantic Gulf Coast States of Region I in Relation to the Fall Line and "Border Counties"

Each dot represents the induction residence of a single case. The heavy line represents the approximate location of the fall line and the shaded area indicates the "border" counties.

Georgia and in the area where Texas, Louisiana, and Arkansas are contiguous. This distribution corresponds very closely with the physiographic area known as the Atlantic and Gulf Coastal Plain. Until relatively recent geologic times, this area was covered by the sea and was delineated along its westernmost and northernmost extent by the former coast line, which is now known as the fall line (3). The approximate position of this former coast line is shown by the heavy line on Figure 3.

Comparisons were next made of the race specific attack rates by induction residence for the areas within the Southeastern states in relation to this geologic landmark. In arriving at these rates, counties were assigned to the "above" or "below fall line" category, depending upon their localization. Since the former coast line transects many contemporary county borders, and since the determination of its exact location in any region may be difficult, the counties traversed by and adjacent to the fall line, which have been designated as border counties, were considered separately. The term "modified" fall line was introduced to represent the composite area of these border counties and is depicted in Figure 3 by the stippled area.

Table IV indicates negro attack rates by induction residence for the areas of the ten states of Region I in relation to the "modified" fall line. It can be seen that for each state a greater number of cases in negroes occurs in the "below fall line" area. Similarly, the attack rate is greater for this area in each of the states, with the exception of Texas. The overall rate for the "below fall line" area in four of the states, Alabama, Georgia, North Carolina, and South Carolina, is 49.0 per 100,000 or five times greater than the 
overall "above fall line" rate of 10.0 per 100,000 for these states. In three other states, Arkansas, Texas, and Virginia, the differences in attack rates between the "above" and "below fall line" areas are not statistically significant. However, in two of these, Arkansas and Virginia, the trend of the rates is the same as that observed in the four states where the differences are significant. Thus, we have a distinct intrastate concentration of the cases in the coastal plain area which appears to be unaccountable for by population distribution within these states.

\section{Relation to other geographic factors}

A number of ecological factors were explored for a possible explanation of this unusual localization. Among these were meteorologic conditions (4), the distribution of plant and animal life (5, $6)$, agricultural practices (7), and overall population densities (8). It was found that none of these factors was overtly associated with the distribution of the cases.
Since the fall line delineates, among other things, the boundaries of geologic formations (9) and major soil groups in the Southeast, attention was directed to a consideration, in a qualitative fashion, of surface materials. A close association appeared to exist between the residences of the cases and some of the soils of the coastal plains. This correlation was strengthened by several additional observations. In the Mississippi Valley, relatively few cases were noted although this is an area with a large negro population. The Alluvial soils, which are found there, differ significantly in character from the other soils of the Southeast. Furthermore, in the area where Texas, Louisiana, and Arkansas are contiguous, there is a reappearance of some of the soils which are present along the eastern portion of the coastal plain. The concentration of cases in this general region appeared to strengthen the preliminary correlation of the cases with these soils. Therefore, a more detailed and quantitative study was made of this relationship.

TABLE IV

Sarcoidosis attack rates among World War II Negro servicemen, by induction residence, according to areas in relation to the "modified" fall line in the South Atlantic Gulf Coast states

\begin{tabular}{|c|c|c|c|c|c|}
\hline State & $\begin{array}{l}\text { Area in } \\
\text { relation to } \\
\text { "modified" } \\
\text { fall line }\end{array}$ & $\begin{array}{l}\text { Negro } \\
\text { selective } \\
\text { service } \\
\text { population }\end{array}$ & $\begin{array}{c}\text { Negro } \\
\text { cases by } \\
\text { induction } \\
\text { residences }\end{array}$ & $\begin{array}{c}\text { Attack } \\
\text { rates } \\
\text { per } \\
100,000\end{array}$ & $\begin{array}{c}\mathrm{X}^{2} \text { of } \\
\text { differences } \\
\text { between } \\
\text { Negro rates }\end{array}$ \\
\hline Alabama & $\begin{array}{l}\text { Above } \\
\text { Below }\end{array}$ & $\begin{array}{l}28,751 \\
25,760\end{array}$ & $\begin{array}{r}4 \\
15\end{array}$ & $\left.\begin{array}{l}13.9 \\
58.2\end{array}\right\}$ & 7.66 \\
\hline Arkansas & $\begin{array}{l}\text { Above } \\
\text { Below }\end{array}$ & $\begin{array}{r}2,142 \\
23,543\end{array}$ & $\overline{8}$ & $\overline{34.0}\}$ & $0.46^{*}$ \\
\hline Florida & Below & 51,188 & 15 & 29.3 & - \\
\hline Georgia & $\begin{array}{l}\text { Above } \\
\text { Below }\end{array}$ & $\begin{array}{l}30,721 \\
26,636\end{array}$ & $\begin{array}{r}3 \\
11\end{array}$ & $\left.\begin{array}{r}9.8 \\
41.3\end{array}\right\}$ & 5.81 \\
\hline Louisiana & Below & 72,323 & 10 & 13.8 & - \\
\hline Mississippi & Below & 86,075 & 17 & 19.8 & 一 \\
\hline North Carolina & $\begin{array}{l}\text { Above } \\
\text { Below }\end{array}$ & $\begin{array}{l}33,498 \\
21,745\end{array}$ & $\begin{array}{r}3 \\
12\end{array}$ & $\left.\begin{array}{r}9.0 \\
55.2\end{array}\right\}$ & 10.38 \\
\hline South Carolina & $\begin{array}{l}\text { Above } \\
\text { Below }\end{array}$ & $\begin{array}{l}17,237 \\
26,214\end{array}$ & $\overline{11}$ & $\overline{42.0}\}$ & $5.67 *$ \\
\hline Texas & $\begin{array}{l}\text { Above } \\
\text { Below }\end{array}$ & $\begin{array}{r}5,318 \\
74,301\end{array}$ & $\begin{array}{r}2 \\
12\end{array}$ & $\left.\begin{array}{l}37.6 \\
16.2\end{array}\right\}$ & 1.30 \\
\hline Virginia & $\begin{array}{l}\text { Above } \\
\text { Below }\end{array}$ & $\begin{array}{l}22,101 \\
24,767\end{array}$ & $\begin{array}{l}4 \\
6\end{array}$ & $\left.\begin{array}{l}18.1 \\
24.2\end{array}\right\}$ & 0.21 \\
\hline Total & $\begin{array}{l}\text { Above } \\
\text { Below } \\
\text { Border }\end{array}$ & $\begin{array}{r}139,768 \\
432,552 \\
91,759\end{array}$ & $\begin{array}{r}16 \\
117 \\
23\end{array}$ & $\left.\begin{array}{l}11.4 \\
27.0 \\
25.1\end{array}\right\}$ & 11.07 \\
\hline
\end{tabular}

* Corrected for continuity. 


\section{SOIL REGIONS OF THE SOUTH}

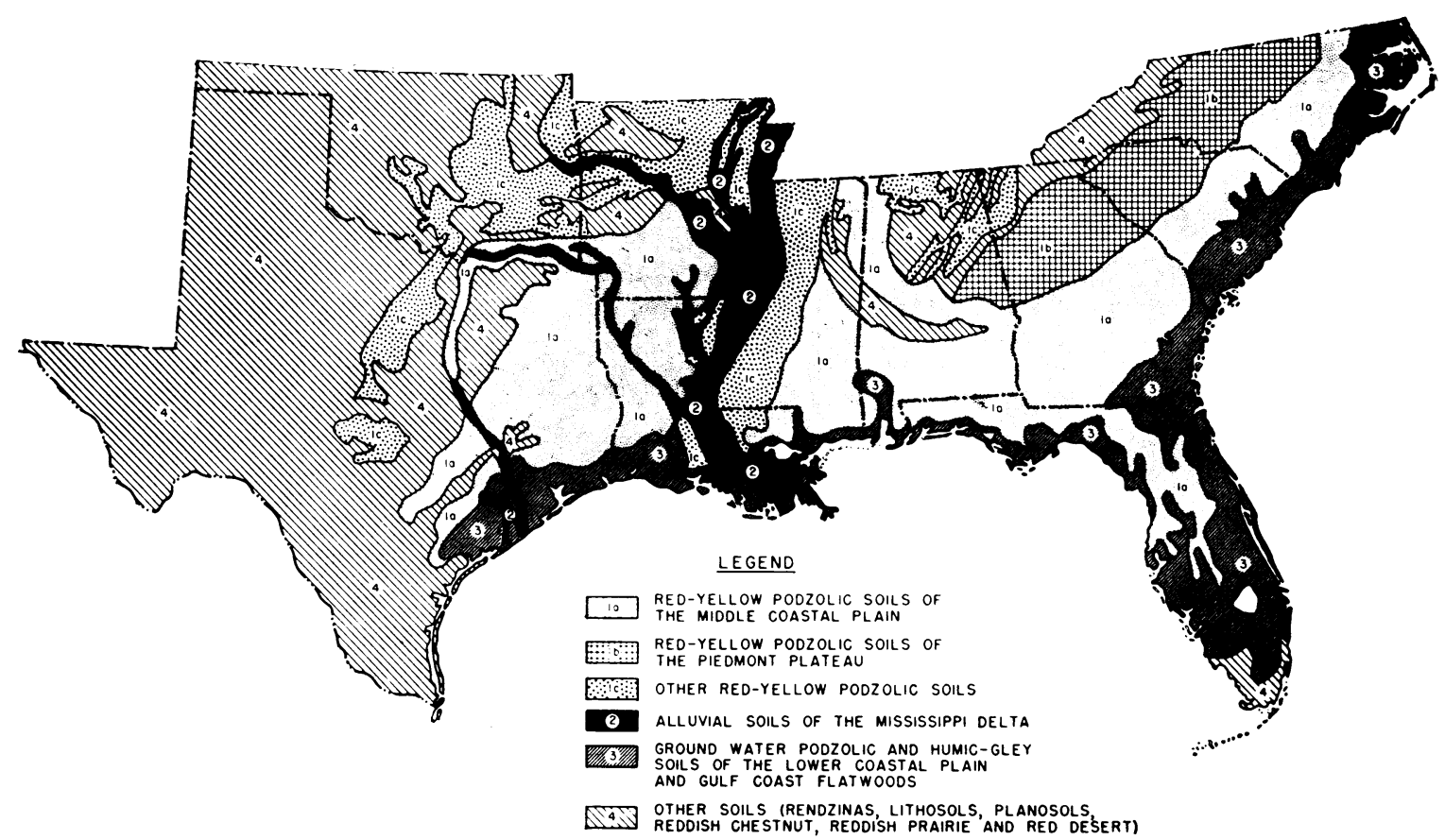

Fig. 4. The General Pattern of the Great Soll Groups in the Southeast

Local details have been submerged in order to present a general view of the significant features on a small map.

\section{Soils of the southeast}

The general pattern of the soil areas in the Southeast is shown in Figure $4 .^{5}$ These soils can be differentiated on the basis of well-defined morphological and other characteristics, such as chemical composition, geologic precursors, native vegetation, and topography $(10,11)$.

The Red-Yellow Podzolic soils form the dominant group in this region, extending from Virginia to Texas. These have light-colored sandy surfaces overlying firm, red to yellow subsoils. They are generally well drained, strongly leached, and low in organic and mineral plant nutrients.

On the basis of variations in one or more of their characteristics, these leached soils can be further classified among a number of subgroups.

5 Since identical soil classification data were not available for Virginia, the subsequent analysis has been restricted to nine of the states in Region I. Older soil classification schemes (10) indicated that the inclusion of Virginia did not significantly alter the correlations obtained between race specific attack rates for sarcoidosis and residence in certain soil areas.
In Figure 4 are outlined The Red-Yellow Podzolic soils of the Middle Atlantic Coastal Plain, subgroup "1a," those of the Piedmont Plateau, subgroup " $1 \mathrm{~b}$," and a miscellaneous subgroup, "1c."

The Alluvial soils occupy the flood plains in the Southeast and form the dominant soils of the Mississippi Valley. They are soils in early stages of profile development, having been affected very little by processes of soil formation. In general, the Alluvial soils in this region are relatively high in organic matter, poorly drained, and neutral in reaction. These have been designated as group " 2 " in Figure 4.

The Humic-Grey and Ground-Water Podzols are poorly drained soils which occur extensively along the Atlantic and Gulf Coasts. These soils, group " 3 " in Figure 4, generally have light-grey sandy leached layers and usually contain little organic matter. Most of these have been derived from beds of unconsolidated sands and sandy clays of relatively recent geological origin.

The remaining soils in the Southeast are com- 
TABLE $V$

Sarcoidosis attack rates among World War II Negro servicemen, by induction residence, according to soil areas of the South Atlantic Gulf Coast states*

\begin{tabular}{|c|c|c|c|c|}
\hline Soil group & $\begin{array}{l}\text { Negro } \\
\text { selective } \\
\text { service } \\
\text { population }\end{array}$ & $\begin{array}{l}\text { Negro } \\
\text { cases by } \\
\text { induction } \\
\text { residence }\end{array}$ & $\begin{array}{l}\text { Attack } \\
\text { rates } \\
\text { per } \\
100,000\end{array}$ & $\frac{(\mathrm{O}-\mathrm{E})^{2}}{\mathrm{E}}$ \\
\hline $\begin{array}{l}\text { Red-Yellow Podzolic soils of the Middle } \\
\text { Coastal Plain (1a) }\end{array}$ & 188,049 & 82 & 43.6 & 30.65 \\
\hline $\begin{array}{l}\text { mont Plateau (1b) } \\
\text { Other Red-Yellow Podzolic soils (1c) } \\
\text { Alluvial soils of the Mississippi Delta (2) }\end{array}$ & $\begin{array}{l}92,542 \\
63,995 \\
55,881\end{array}$ & $\begin{array}{r}6 \\
11 \\
6\end{array}$ & $\begin{array}{r}6.5 \\
17.2 \\
10.7\end{array}$ & $\begin{array}{r}11.72 \\
1.21 \\
4.09\end{array}$ \\
\hline $\begin{array}{l}\text { Ground-Water Podzolic and Humic-Clay } \\
\text { soils of the Lower Coastal Plain (3) } \\
\text { Other soils } \dagger(4)\end{array}$ & $\begin{array}{r}116,376 \\
84,979\end{array}$ & $\begin{array}{l}23 \\
16\end{array}$ & $\begin{array}{l}19.8 \\
18.8\end{array}$ & $\begin{array}{l}0.83 \\
0.91\end{array}$ \\
\hline Totals & 601,882 & 144 & 23.9 & $\begin{aligned} \mathrm{X}^{2} & =49.41 \\
\mathrm{p} & <0.001\end{aligned}$ \\
\hline
\end{tabular}

* Includes Alabama, Arkansas, Florida, Georgia, Louisiana, Mississippi, North Carolina, South Carolina, Texas.

† Includes Rendzinas, Lithosols, Plenosols, Reddish Chestnut, Reddish Prairie and Red Desert soils.

posed of a heterogeneous group of shallow, stony soils (Lithosols), clay pan soils (Planosols), black soils (Rendzinas), and subhumid and semiarid soils (Reddish-Prairie and Reddish-Chestnut), all of which have been combined into group "4" in Figure 4.

\section{Negro attack rates by soils}

Race specific attack rates for negroes by induction residence were determined for the various soil areas in the Southeast, as shown in Table V. Although the number of white cases in relation to each soil group was too small to make valid comparisons of the attack rates between the groups, the trends observed were similar to those among the negro patients.

The negro attack rates range from 6.5 per 100,000 for the soils of the Piedmont Plateau above the fall line to 43.6 per 100,000 for the soils of the Middle Coastal Plain below the fall line. The attack rate for the Alluvial soil area is somewhat low, 10.7, but the remaining rates appear to be quite uniform. Thus, rates of 17.2, 19.8, and 18.8 per 100,000 were noted for the group " $1 c$," group " 3 ," and group "4" soil areas, respectively.

It is apparent that the greatest differences in attack rates exist between the soils of the Middle Coastal Plain and those of the Piedmont Plateau, where a ratio of almost 7 to 1 in these rates is observed. This ratio should be contrasted to the much smaller 3 to 1 ratio which was found be- tween the negro attack rates for Regions I and III.

No significant localization of the cases by induction residence appeared to exist within the Red-Yellow Podzolic soils of the Middle Coastal Plain itself. Thus, negro attack rates in relation to this particular soil group for each of the nine Southeastern states, as shown in Table VI, are essentially equivalent. The one exception, perhaps, is North Carolina, where the rate of 71.3 per 100,000 is somewhat higher than those for the other states. Even with this elevated rate, however, the total chi square of the differences, 10.48, is not statistically significant.

TABLE VI

Sarcoidosis attack rates among World War II Negro servicemen from the " $1 a$ " soil area, according to states

\begin{tabular}{|c|c|c|c|c|}
\hline State & $\begin{array}{l}\text { Negro } \\
\text { selective } \\
\text { service } \\
\text { population }\end{array}$ & $\begin{array}{c}\text { Negro } \\
\text { cases by } \\
\text { induction } \\
\text { residence }\end{array}$ & $\begin{array}{c}\text { Attack } \\
\text { rates } \\
\text { per } \\
100,000\end{array}$ & $\frac{\frac{(\mathrm{O}-\mathrm{E})^{2}}{\mathrm{E}}}{\begin{array}{c}\text { (for Negro } \\
\text { cases) }\end{array}}$ \\
\hline $\begin{array}{l}\text { Alabama } \\
\text { Arkansas } \\
\text { Florida } \\
\text { Georgia } \\
\text { Louisiana } \\
\text { Mississippi } \\
\text { North Carolina } \\
\text { South Carolina } \\
\text { Texas }\end{array}$ & $\begin{array}{l}27,175 \\
10,464 \\
10,001 \\
27,059 \\
18,574 \\
20,898 \\
22,449 \\
19,374 \\
32,055\end{array}$ & $\begin{array}{r}13 \\
7 \\
6 \\
13 \\
5 \\
8 \\
16 \\
5 \\
9\end{array}$ & $\begin{array}{l}47.8 \\
66.9 \\
60.0 \\
48.0 \\
26.9 \\
38.3 \\
71.3 \\
25.8 \\
28.1\end{array}$ & $\begin{array}{l}0.12 \\
1.25 \\
0.58 \\
0.12 \\
1.19 \\
0.13 \\
3.92 \\
1.38 \\
1.79\end{array}$ \\
\hline Totals & 188,049 & 82 & \multicolumn{2}{|c|}{$\begin{array}{r}\mathrm{X}^{2}=10.48 \\
43.6^{0.20<p<0.30}\end{array}$} \\
\hline
\end{tabular}


Race specific attack rates were determined for each of the seventeen minor soil series which compose the leached soils of the Middle Coastal Plain. Because of the generally small number of cases, it was difficult to compare the rates, which were found to be quite variable. However, no significant concentration of induction residences was observed in relation to any of these soil series, as can be observed from Figure 5. There, the approximate locations of the individual soil series are indicated by the alphabetical characters. Thus, the factor (or factors) which influence the concentration of cases by induction residence in the Middle Coastal Plain area appears to be distributed with some uniformity.

\section{Factors of migration}

Admittedly, these efforts to quantitate the association of the cases of sarcoidosis with certain soil groups are crude. However, the previously mentioned influence of migration, particularly for the negroes, seems to minimize the observed differences. For example, of the 52 negroes inducted from Regions II and III, only 17 were born in this area; 35 had been born in the Southeast. Of these 35 migrants, 22, or 63 per cent were born in the area of the Middle Coastal Plain soils. Since it is reasonable to assume that the majority of these individuals had migrated to northern areas as recently as the pre-war period of national mobilization, exposure to the soils may have been of considerable duration.

The uncertainties introduced by migration can be minimized by considering only those cases whose birthplace and induction residence were located in the same or adjacent counties, the socalled "lifetime residents." It would seem reasonable to assume that these individuals had a pro-

\section{DISTRIBUTION OF SARCOIDOSIS IN 9 SOUTHEASTERN STATES BY INDUCTION RESIDENCE}

IN RELATION TO CERTAIN OF THE RED-YELLOW PODZOLIC SOILS

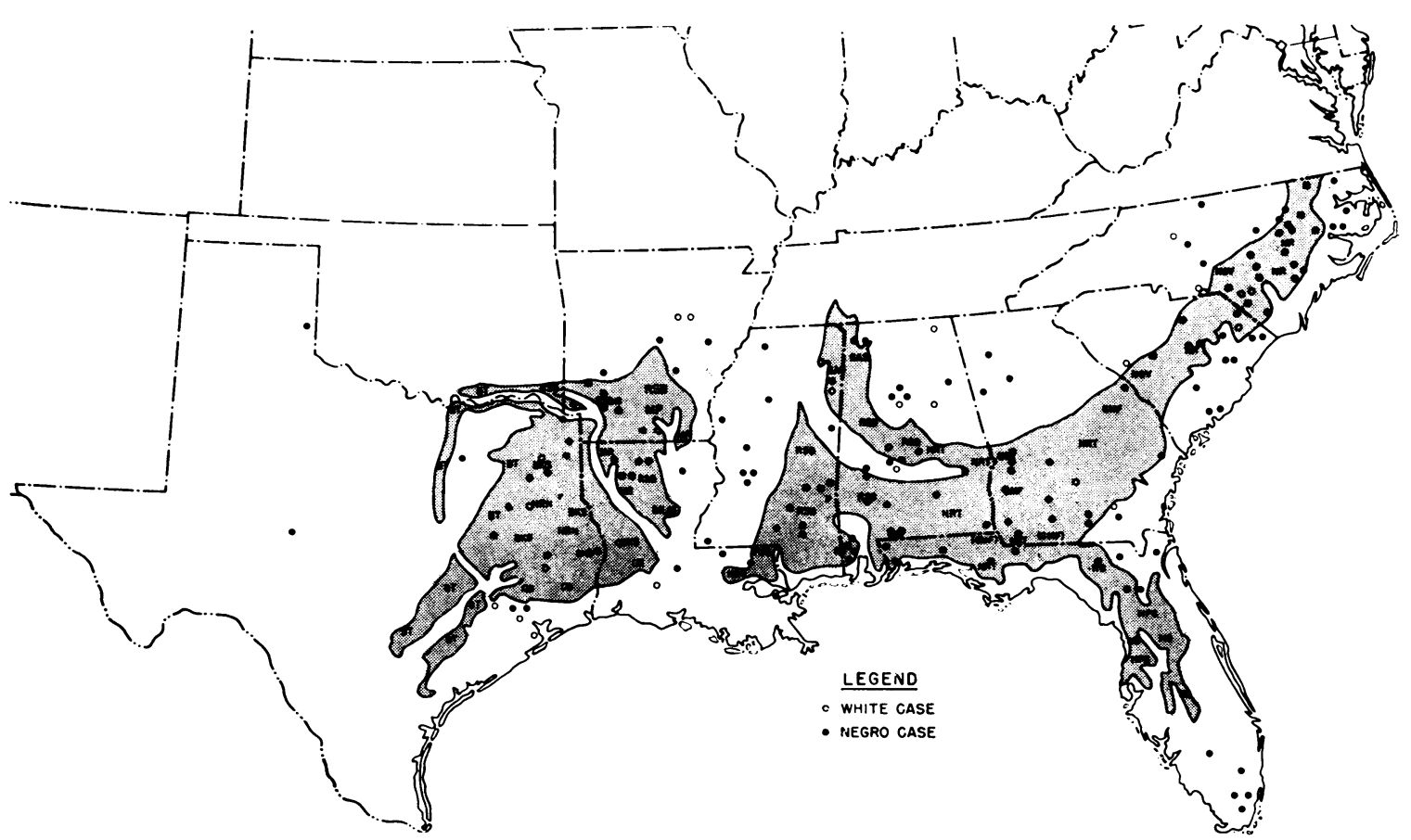

Fig. 5. The Induction Residences of a Group of 171 Cases of Sarcoidosis in Nine of the South AtlanticGulf Coast States

The residences are shown in relation to the 17 minor soil series, indicated by the alphabetical characters which. compose the "1a" Red-Yellow Podzolic soils. 
longed contact with the soils in and about their county of induction, whereas a similar assumption would be less likely to apply in the case of the migrants. Of the 113 negroes with sarcoidosis inducted from Region I who could be classified as "lifetime residents," 73 came from the Middle Coastal Plain soil area and 4 from the leached soil area of the Piedmont Plateau. The total negro selective service populations for these areas, inclusive of immigrants and permanent residents, were approximately 188,000 and 93,000 , respectively. While these figures are not deemed sufficiently comparable to calculate valid attack rates, the crude rates which may be derived are 39 per 100,000 and 4 per 100,000 indicating differences of 10 to 1 or greater. As noted previously, the attack rates based on the total number of cases inducted from these areas were 43.6 per 100,000 and 6.5 per 100,000 , respectively, representing a difference of slightly less than 7 to 1 .

Unfortunately, chronological residence data are not available for all the cases from Region I. If such were at hand, it would be feasible to determine man-years of experience for all the soil areas. The significant correlations obtained by use of "lifetime residents" suggest that such a method of analysis would strengthen the relationship between sarcoidosis and the soils of the Middle Atlantic Coastal Plain.

\section{Urban-rural occurrence of the disease}

By grouping the counties of the ten Southeastern states according to population density, sarcoidosis attack rates can be calculated for white and negro servicemen from these composite county areas. In Table VII the rates for negro military personnel are shown. It can be seen that an inverse relationship exists between these rates and county population density. For the counties with 19 or fewer inhabitants per square mile, presumably those which are most rural in character, the rate of 48.7 per 100,000 is highest. On the other hand, a much lower rate, 15.2 per 100,000 , is found among the servicemen from the counties with population densities of 100 or more people per square mile, areas which presumably are most urbanized. The attack rates among negro servicemen from counties with intermediate population densities lie in between these extremes.
TABLE VII

Sarcoidosis attack rates among World War II Negro servicemen from 10 South Atlantic Gulf Coast states* according to population density of county of induction

\begin{tabular}{|c|c|c|c|c|}
\hline $\begin{array}{l}\text { Population } \\
\text { densityt of } \\
\text { county of } \\
\text { induction }\end{array}$ & $\begin{array}{l}\text { Negro } \\
\text { selective } \\
\text { service } \\
\text { population }\end{array}$ & $\begin{array}{l}\text { Negro } \\
\text { cases by } \\
\text { induction } \\
\text { residence }\end{array}$ & $\begin{array}{c}\text { Attack } \\
\text { rates } \\
\text { per } \\
100,000\end{array}$ & $\frac{(O-E)^{2}}{E}$ \\
\hline $\begin{array}{l}\text { Less than } 20 \\
20-49 \\
50-99 \\
100 \text { and over }\end{array}$ & $\begin{array}{r}20,560 \\
219,332 \\
187,434 \\
236,753\end{array}$ & $\begin{array}{l}10 \\
71 \\
39 \\
36\end{array}$ & $\begin{array}{l}48.6 \\
32.4 \\
20.8 \\
15.2\end{array}$ & $\begin{array}{l}5.63 \\
7.38 \\
0.57 \\
6.91\end{array}$ \\
\hline Total & 664,079 & 156 & & $\begin{array}{c}20.49 \\
0.001\end{array}$ \\
\hline
\end{tabular}

* Includes Alabama, Arkansas, Florida, Georgia, Louisiana, Mississippi, North Carolina, South Carolina, Texas, and Virginia.

$\dagger$ Population per square mile (1940), from County Data Book, U. S. Bureau of the Census, 1947.

The overall differences between these rates are statistically highly significant $\left(\mathrm{X}^{2}=20.49, \mathrm{p}<\right.$ $.001)$. The small number of white cases in relation to each county group made it difficult to evaluate the differences between the attack rates observed. However, the overall trend of these rates was the same as that found among negro servicemen.

Figure 6 illustrates the population density distribution for the counties of the ten-state region. In comparing this with Figure 3, which illustrates the distribution of the cases of sarcoidosis in relation to the modified fall line, it appears that the more densely populated counties are located in the area of the Piedmont Plateau (above the fall line) whereas the distribution of the less densely populated counties appears to conform to that of the Atlantic Coastal Plain (below the Fall line).

In view of the previously demonstrated correlation between race specific attack rates for sarcoidosis and residence in certain soil areas in the Southeast, it was deemed desirable to determine whether urban-rural localizing factors were acting independently of these soil associations. Therefore, attack rates were computed for servicemen from the various soil areas of the Southeast according to the population density distribution of the various counties.

These rates for negro servicemen from the Red-Yellow Podzolic soil area of the Middle Atlantic Coastal Plain in nine of the Southeastern states having identical soil classification data are 


\section{POPULATION DENSITY DISTRIBUTION BY COUNTIES 10 SOUTHEASTERN STATES}

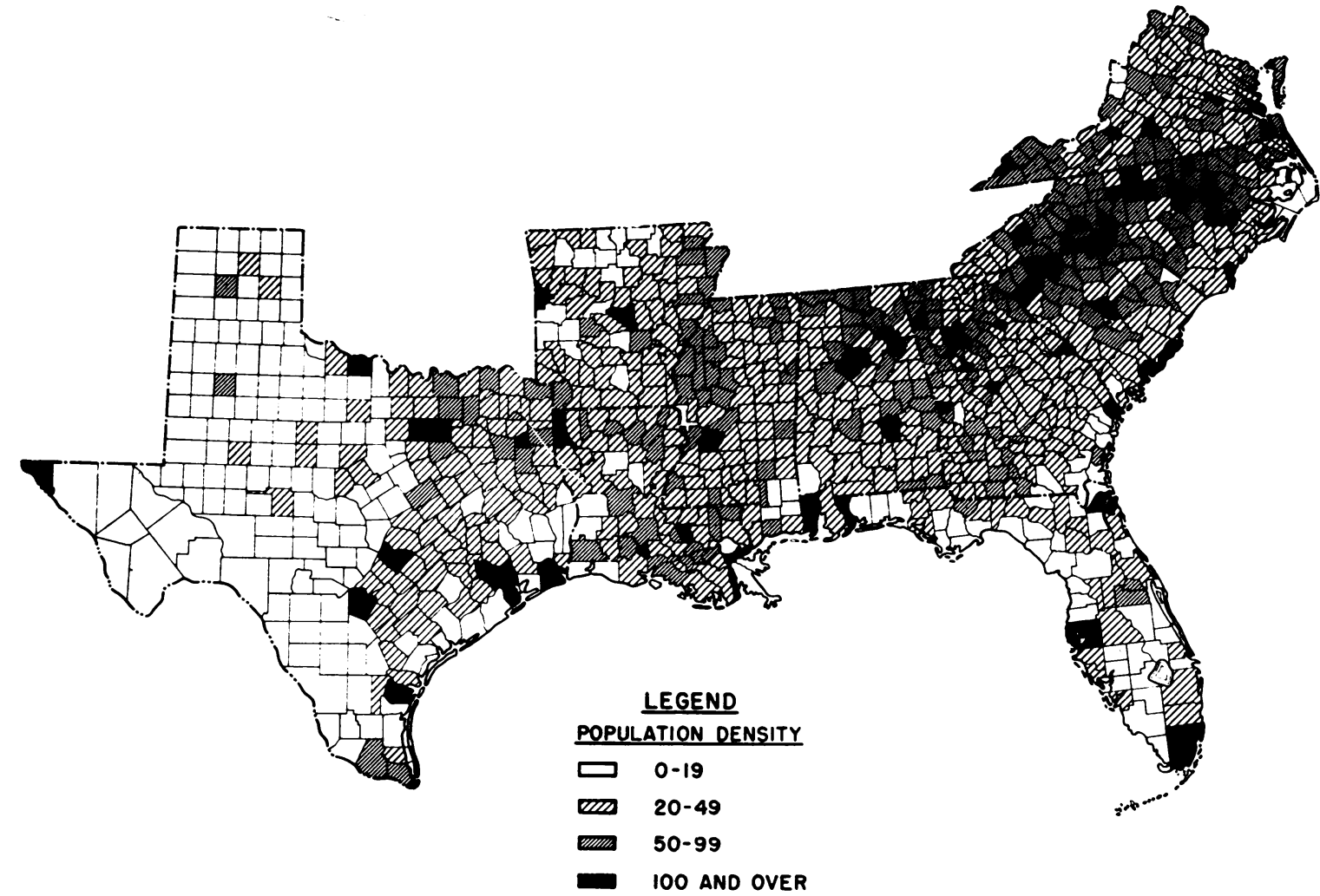

Fig. 6. The Population Density Distribution by Counties in Ten Southeastern States

Population density is expressed as number of inhabitants per square mile and refers to Bureau of the Census data from the 1940 census.

shown in Table VIII. This "1a" soil area, as designated previously, represents the site of maximal intraregional concentration of the cases, both

TABLE VIII

Sarcoidosis attack rates among World War II Negro servicemen from the Middle Coastal Plain soil area,* by induction residence, according to population density of county of induction

\begin{tabular}{lrcc}
\hline \hline $\begin{array}{c}\text { Population } \\
\text { density† of } \\
\text { county of } \\
\text { induction }\end{array}$ & $\begin{array}{c}\text { Negro } \\
\text { selective } \\
\text { service } \\
\text { population }\end{array}$ & $\begin{array}{c}\text { Negro } \\
\text { cases by } \\
\text { induction } \\
\text { residence }\end{array}$ & $\begin{array}{c}\text { Attack } \\
\text { rates } \\
\text { per } \\
100,000\end{array}$ \\
\hline Less than 20 & 7,639 & 7 & 91.6 \\
$20-49$ & 93,612 & 37 & 39.5 \\
$50-99$ & 56,000 & 25 & 44.6 \\
100 and over & 30,798 & 13 & 42.2 \\
$\quad$ Total & $-\frac{13}{82}$ & $\mathbb{4 3 . 6}$
\end{tabular}

* Middle Coastal Plain Soil area in 9 states, including Alabama, Arkansas, Florida, Georgia, Louisiana, Mississippi, North Carolina, South Carolina, and Texas.

$\uparrow$ Population per square mile (1940), from County Data Book, U. S. Bureau of the Census, 1947. by birthplace and induction residence. The rate of 91.8 per 100,000 among the servicemen from the counties with lowest population densities, 19 or fewer inhabitants per square mile, is more than twice as great as the overall rate of 41.7 per 100 ,000 among servicemen from the more densely populated counties. Although the number of cases in the former category is small, the difference between these rates is statistically significant $(p<0.04)$. The remaining attack rates among servicemen from counties with population densities of $20-49,50-99$, and 100 or more inhabitants per square mile, show no consistent downward trend, in contrast to the findings for the whole of the ten-state region.

On the other hand, the attack rates among negro servicemen from the remaining soil areas of the nine-state region exclusive of the " $1 \mathrm{a}$ " Middle Coastal Plain area are shown in Table IX. 
TABLE IX

Sarcoidosis attack rates among World War II servicemen from nine South Atlantic Gulf Coast states, ${ }^{*}$ exclusive of the Middle Coastal Plain soil area, according to population density of county of induction

\begin{tabular}{lccc}
\hline \hline $\begin{array}{c}\text { Population } \\
\text { densityt of } \\
\text { county of } \\
\text { induction }\end{array}$ & $\begin{array}{c}\text { Negro } \\
\text { selective } \\
\text { service } \\
\text { population }\end{array}$ & $\begin{array}{c}\text { Negro } \\
\text { cases by } \\
\text { induction } \\
\text { residence }\end{array}$ & $\begin{array}{c}\text { Attack } \\
\text { rates } \\
\text { per } \\
100,000\end{array}$ \\
\hline Less than 20 & 12,640 & 3 & 25.7 \\
$20-49$ & 108,294 & 27 & 24.9 \\
$50-99$ & 114,060 & 11 & 9.6 \\
100 and over & 178,779 & 21 & 11.7 \\
Total & 413,773 & $\frac{62}{15.0}$ & 15.7
\end{tabular}

* Includes Alabama, Arkansas, Florida, Georgia, Louisiana, Mississippi, North Carolina, South Carolina, and Texas.

† Population per square mile (1940) from County Data Book, U. S. Bureau of the Census (1947).

Rates of 23.7 and 24.9 per 100,000 were obtained for servicemen from counties with population densities of 19 or fewer, and 20 to 49 inhabitants per square mile, respectively. The overall rate for these composite county areas, 24.9 per 100,000 , is statistically significantly higher $(p<0.001)$ than the overall rate of 10.9 per 100,000 observed among servicemen from counties with greater population densities, 50 to 99 , and 100 or more inhabitants per square mile, respectively. Again, there is no consistent downward trend in the rates as shown in Table VII for the entire tenstate region, but the qualitative relationships remain unchanged, i.e., higher attack rates prevail among servicemen from counties with low population densities, which presumably are most rural in character. These findings suggest the presence of a rural localizing factor in the occurrence of sarcoidosis which may be independent of any primary soil relationship.

By grouping the counties of the " $1 \mathrm{a}$ " Middle Coastal Plain soil area according to population size, a similar correlation can be demonstrated, as shown in Table $\mathrm{X}$. Here, a threefold difference is evident between the attack rate of 124.4 per 100 ,000 among negro servicemen from counties with the smallest total populations, less than 10,000 inhabitants, and the overall rate of 41.1 per 100 ,000 among servicemen from counties with the smallest total populations, less than 10,000 inhabitants, and the overall rate of 41.1 per 100,000 among servicemen from counties with more than 10,000 inhabitants. Although the former rate is based on only seven cases, the difference between these rates is statistically significant $(p<0.01)$. Again, no consistent downward trend in the rates is apparent among the more populous counties; however, the rate among servicemen from counties with populations of 100,000 or more, is only 25.7 per 100,000 , a somewhat lower value than the others.

A further suggestion of the rural localization of sarcoidosis is provided by other Bureau of the Census data. Table XI presents the attack rates among negro servicemen from the Middle Atlantic Coastal Plain soil area according to the proportion of inhabitants classified as "rural," i.e., those residents in communities with less than 2500 people, among the negro population of each county. A direct correlation exists between these rates and the percentage of "rural" negro inhabitants. Thus, among negro servicemen from counties where 90 to 100 per cent of the negroes are in the "rural" category, the attack rate of 54.7 per 100,000 is highest. This declines to a rate of 29.0 per 100,000 for the servicemen from counties with less than 49 per cent "rural" negro inhabitants. Although the differences between these rates are only of borderline statistical significance, the trend is in conformity with previous findings.

Admittedly, these attempts to demonstrate a rural localization of sarcoidosis among World War II servicemen are also crude. The factor of migration, among others, again introduces some uncertainty in the interpretation of the findings and the unavailability of residence data pertaining to

TABLE $\mathrm{X}$

Sarcoidosis attack rates among World War II Negro servicemen from the Middle Coastal Plain soil area, ${ }^{*}$ by induction residence, according to population size of county of induction

\begin{tabular}{lccc}
\hline $\begin{array}{c}\text { Population sizet } \\
\text { of county of } \\
\text { induction }\end{array}$ & $\begin{array}{c}\text { Negro } \\
\text { selective } \\
\text { service } \\
\text { population }\end{array}$ & $\begin{array}{c}\text { Negro } \\
\text { cases by } \\
\text { induction } \\
\text { residence }\end{array}$ & $\begin{array}{c}\text { Attack } \\
\text { rates } \\
\text { per } \\
100,000\end{array}$ \\
\hline Less than 10,000 & 5,622 & 7 & 124.5 \\
$10,000-19,999$ & 30,502 & 14 & 45.9 \\
$20,000-49,999$ & 95,854 & 39 & 40.7 \\
$50,000-99,999$ & 40,514 & 18 & 44.4 \\
100,000 and over & 15,557 & 4 & 25.7 \\
\multicolumn{1}{c}{ Total } & 188,049 & -72 & 43.6 \\
\hline
\end{tabular}

* Middle Coastal Plain soil area in nine states, including Alabama, Arkansas, Florida, Georgia, Louisiana, Mississippi, North Carolina, South Carolina, and Texas.

† 1940 population, from County Data Book, U. S. Bureau of the Census, 1947. 
TABLE XI

Sarcoidosis attack rates among World War II Negro servicemen from the Middle Coastal Plain soil area,* by induction residence, according to per cent of rural inhabitants among Negro population of county of induction

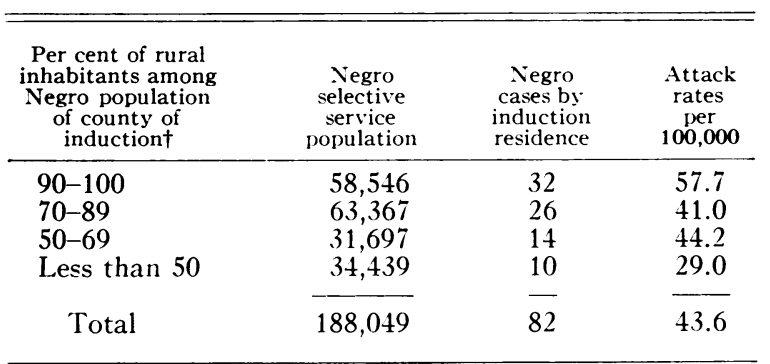

* Middle Coastal Plain soil area in Alabama, Arkansas, Florida, Georgia, Louisiana, Mississippi, North Carolina, South Carolina, and Texas.

† From 1940 Bureau Census Data.

the pre-induction period precludes any attempt to correct for this variable. The importance of the latter is evident from the findings on the follow-up studies of 40 cases in the ten-state Southeastern region. Sixteen, or 40 per cent of these patients, lived in a community with a population of 2500 or greater at the time of their induction into the armed forces, and by the criteria of the Bureau of the Census, could be termed "urban" inhabitants. However, chronological residence histories from these sixteen individuals revealed that eleven had spent more than half their lives on farms or had engaged in farming as an occupation prior to military service, and therefore must have had prolonged contact with rural environments. It would seem likely that similar residence information from more intensive follow-up studies of all the cases would serve to strengthen the relationship between the disease and previous rural residence.

\section{DISCUSSION}

An analysis of the residence data from this group of 297 military cases of sarcoidosis revealed a distinct concentration of their birthplaces and induction residence in the Southeast. Within this region, a significant correlation was observed between race specific attack rates and residence in areas defined by the distribution of certain specific soil groups. In addition, significantly higher attack rates were noted among military personnel from the Southeast whose residences at the time of entry into the armed forces were located in the relatively rural counties, as evidenced by low popu- lation density and small population size of these areas.

Since sarcoidosis is not a reportable disease, there is a paucity of morbidity data from which any comparison might be made with the cases which occur in the general population. Israel and Sones (12) have recently described their experiences with cases of sarcoidosis seen in Philadelphia. Of the 74 negroes in their group, 64 were born in the South, a distribution greatly disproportionate to the estimated percentage of southernborn negroes in that city.

Some clata from a group of civilian cases of sarcoidosis in North Carolina (13) and South Carolina (14) provided an opportunity to compare the geographic localization of these cases with that observed among the military group. Of a total of 14 individuals suspected of having tuberculosis but later diagnosed as sarcoidosis, during 1949 and 1950 in South Carolina, 12 resided in the "below fall line" area. Nine of these resided within counties containing the leached soils of the Middle Coastal Plain as the predominant soil types. In North Carolina, 17 deaths were reported from Boeck's sarcoid from 1949 to 1951. Of the total, four resided in counties above the fall line, six lived in "border" counties and seven resided in the "below fall line" area. Of the 13 deaths in "border" and "below fall line" counties, nine had lived where the leached Middle Coastal Plain soils abounded. Thus, these data, while inappropriate for the computation of sarcoidosis attack rates for different areas, would appear to be consistent with the observations on the military cases inducted from these states.

On the other hand, in analyzing the birthplaces of 177 patients with sarcoidosis diagnosed at the Mayo Clinic from 1940 through 1951, Carr and Gage (15) did not find that the disease was more common in patients who came from the Southeastern part of the United States than in those who came from other areas. Apparently, such factors as age, sex, race, and severity of disease could not explain the difference in distribution from that which had been reported for the group of military cases (2). It should be pointed out, however, that the comparison between the geographic distribution of cases and the total population at the Mayo Clinic does not provide any precise information as to the relative incidence of the disease 
among an unselected population in a given area. The series of Carr and Gage therefore is not strictly comparable to the military group.

The evidence that Boeck's sarcoid occurs with greater frequency among inhabitants of rural areas is in accord with the suggestion that soils may be determinants in the occurrence of the disease. Longcope and Freiman (16) in confirming an earlier observation of Lomholt (17), noted that sarcoidosis often affected farm laborers and those who live in country districts. Whitehead (18) and Cone (19) refer to similar observations. In relating calcareous crystalline material in soils to the pathogenesis of lesions characteristic of sarcoidosis, Refvem (20) noted ". . . that people living in the country are preferably attacked by Boeck's disease, especially farmers, gardners, etc." Israel and Sones (12) reported that of ten cases of sarcoidosis in white persons seen in Philadelphia only one had been a life-long resident of that city. They noted that "Sarcoidosis would appear to be extremely rare among what is the largest group in this country, the native-born urban white."

The higher attack rates of sarcoidosis among the rural inhabitants of the Southeastern United States, its apparent predilection for negroes and for those living in certain soil areas presents a challenging and perplexing problem. If sarcoidosis is a manifestation of a single etiologic agent, the widespread occurrence of cases in this country would indicate that such an agent is not confined to the Southeast. However, the distinct aggregation of military cases in this area and the suggestion of a similar distribution among civilian cases leads to speculations which may point to further investigation.

It is conceivable that the observed geographic localization of the disease is the result of a) the presence of a highly favorable environment in areas within the Southeast for the growth, propagation, or transmission of an etiologic agent or agents, or b) an alteration in the susceptibility of the population of these areas which predisposes them to the action of some agent which elsewhere might possess a very low grade or altered pathogenecity.

The role of possible host factors in the localization of sarcoidosis is suggested by experiences with pellagra in this country. The concentration of the latter disease in the Southeast could be re- lated largely to the socio-economic status and consequent dietary habits of the affected population, with contributory or secondary factors, such as infectious diseases, influencing its incidence at a particular time or place (21). Similarly, dietary peculiarities and the socio-economic status of the population in certain areas of the Southeast may enhance their resistance to the inciting factor of sarcoidosis; however, little information is available on this point.

The data pertaining to the unusually high incidence of sarcoidosis among negroes in this country also suggest an influence of host susceptibility. Of the total of 523 cases reported in the American literature up to 1952,385 , or 73.4 per cent, were of this race (16). The 26 to 1 ratio between the overall negro and white attack rates in the present series of cases emphasizes this racial predilection. In contrast are the reports from Europe and elsewhere which indicate a high frequency of sarcoidosis in the white race (22). Schönholzer found 67 cases of sarcoidosis among 516,879 Swiss army recruits subjected to mass radiographic examinations, an incidence of 13 per 100,000 (23). This rate compares much better with the overall attack rate in negroes of 18 per 100,000 , than the white rate of 0.7 per 100,000 among American servicemen. Although these two series are not strictly comparable, the results suggest that factors other than inherent racial susceptibility may be influencing the higher prevalence of sarcoidosis among negroes in this country. Thus, sociologic and environmental factors, such as those suggested to account for the significantly higher incidence of venereal diseases among this group (24), may similarly contribute to a susceptibility for Boeck's sarcoid.

The possible concentration of an etiologic agent in some of the soils of the Southeast is brought to mind by the somewhat similar distribution of hookworm disease in the sandy areas of this region (25), and the greater prevalence of this parasitic infection among rural inhabitants (26). Furthermore, recent epidemiologic studies of various mycotic diseases, particularly histoplasmosis and coccidioidomycosis, indicate that their distribution is restricted to regions containing soils favorable for the growth and dissemination of the causative fungi (27-29). By analogy, it can be postulated that some helminth, bacterium, fungus, or virus 
giving rise to sarcoidosis may find certain of the Red-Yellow Podzolic soils of the Southeast the best natural media in which to thrive and thus result in the described localization of the disease.

Other factors, such as the role of intermediate vectors, may account for the circumscribed distribution of Boeck's sarcoid. The Southeastern localization of typhus and malaria can be correlated with the distribution of the tropical rat flea (Xenopsylla cheopis) and certain species of mosquitoes (Anopheles quadrimaculatus) (30, 31 ). In these instances the concentration and migration of the rat, as well as climatic conditions $(32,33)$, and the presence of impounded water and other suitable breeding places (34), rather than any specific soil characteristics, appear to be the factors which confine these respective arthropods to this region. However, certain insects are restricted to specific soil areas, thereby localizing disease agents for which they are the natural vector. Acute conjunctivitis in the South and the distribution of the sand gnat, (Hippelates pusio), may be such a case in point $(35,36)$. Again by analogy, it is possible that some intermediate arthropod vector, in close association with certain soils, serves as an effective transmitter of the etiologic agent of sarcoidosis. However, the lack of any evidence to incriminate an intermediate vector in the transmission of the disease and the lack of any knowledge concerning an arthropod distribution which conforms to that observed for the military cases casts some doubt upon such an hypothesis.

The plant and animal life of the soil areas in which cases of sarcoidosis are concentrated bear scrutiny for a possible etiologic relationship to the disease. In addition, the chemical differences between the various soils of the Southeast might have some relation to the localization of Boeck's sarcoid.

In regard to the latter, the Red-Yellow Podzolic soils of the Piedmont Plateau (where relatively few cases of sarcoidosis resided) contain a strikingly lower percentage of silica and higher percentages of alumina and potash than do the soils of the middle Atlantic Coastal Plain (10). These differences and the resemblance of the pulmonary forms of sarcoidosis to some of the pneumoconioses suggest the possibility that soils may be directly implicated in the pathogenesis of
Boeck's sarcoid. In support of this are the observations of Refvem, who demonstrated crystalline material, which he assumed to be derived from calcareous spars in the soil, in biopsy specimens of 4 of 100 patients with sarcoidosis (20). Ayres, Ober, and Hamilton are of the opinion that many of the strictly localized sarcoid lesions of the skin, following trauma, are actually a form of silicosis (37), and similar contentions have been made by other workers $(38,39)$. Experimentally, Gardner was able to reproduce in rabbits, guinea pigs, and rats, granulomatous lesions resembling those of sarcoidosis, following the administration of particles of silicon dioxide (40).

Suggestions have been made of a relationship between sarcoidosis and the chronic form of beryllium poisoning (41). Although there are many similarities in clinical features between the two, certain differences have been found (42). Furthermore, as Freiman has noted (43), the relatively recent industrial use of beryllium compounds makes these agents unlikely causes for any great numbers of cases of sarcoidosis. However, the inability of Dutra, Cholak, and Hubbard (44) to recover abnormal quantities of beryllium from some lesions of chronic berylliosis, illustrates the difficulty of evaluating possible relationships.

The possibility does exist that exposure to unusual amounts of naturally-occurring beryllium in the soils of the Southeast might have accounted for the aggregation of cases in the middle Atlantic Coastal Plain. Soils in this area were derived from the granitic rocks of the Appalachian Mountains which represent the major concentration of beryllium containing surface ore in the United States. Similarly, such beryllium containing rocks have their greatest concentration in Europe in the Scandinavian countries where sarcoidosis is quite prevalent. Analysis of soil samples obtained in close proximity to the lifetime residence of several of the military cases revealed, by the specific gravity flotation method, the presence of occasional small fragments of beryllium containing rock (44). Chemical and spectrographic analyses carried out by Hodge, Toribara, Steadman, Cholak, and Hubbard, confirmed the presence of beryllium in these samples, although not in any unusual concentrations $(45,46)$. However, the need for caution in relating sarcoidosis to berylliosis and other forms of pneumoconioses which 
might result from any association with soils must be stressed, in view of the diversity of agents that can induce tissue reactions closely simulating the sarcoid granuloma.

Many hypotheses relating to factors of host susceptibility or to characteristics necessary for the propagation and transmission of an etiologic agent may be invoked to account for the observed concentration of cases in certain areas of the Southeast. Undoubtedly, other possibilities exist which have not been mentioned. Any working hypothesis should be in accord with the available epidemiologic knowledge of sarcoidosis in this country ; namely, its apparent predilection for negroes, its concentration in certain soil areas, and its apparent greater relative frequency among rural inhabitants. The newly defined hyper-endemic sarcoidosis area in the Southeast would appear to warrant more intensive study in an effort to elucidate the many obscurities still surrounding the etiology and pathogenesis of this disease.

\section{SUMMARY}

An epidemiologic study of 350 cases of sarcoidosis in military personnel during World War II has indicated the occurrence of this disease with a significantly greater frequency among those whose birthplace is in the Southeastern United States. Residence in a rural area further favors development of the disease.

The ratio of negro to white cases of 18 to 1 accounts in part only for this geographic distribution. The occurrence of sarcoidosis is greater in patients living within certain regions of this endemic area. A close association between the distribution of certain soil types with these regions was noted. Thus, residence in rural areas of the Southeast, particularly of negroes, within regions of a fine sandy soil type appears to favor the development of sarcoidosis. The possible implications of these findings are discussed.

\section{ACKNOWLEDGMENT}

The authors gratefully acknowledge the selective service data provided by Mr. Kenneth H. McGill, Research and Statistics Chief, National Selective Service; the soil classification data provided by Dr. Roy W. Simonson, Assistant Chief, Division of Soil Survey, U. S. Department of Agriculture; and the statistical assistance of Mrs. Bricelyn Cantey, and Mr. David Sack, Communi- cable Disease Center. Appreciation is also extended to Dr. Alexander D. Langmuir, Chief, Epidemiology Branch, Communicable Disease Center, for his invaluable assistance and advice during the course of this study. Miss Jewell Schaeffer gave invaluable assistance in compiling and analyzing clinical records of all patients.

\section{REFERENCES}

1. Ricker, W., and Clark, M., Sarcoidosis. A clinicopathologic review of three hundred cases, including twenty-two autopsies. Am. J. Clin. Path., 1949, 19, 725.

2. Michael, M., Jr., Cole, R. M., Beeson, P. B., and Olson, B. J., Sarcoidosis. Preliminary report on a study of 350 cases with special reference to epidemiology. Am. Rev. Tuberc., 1950, 62, 403.

3. Fenneman, N. M., Physiography of Eastern United States. New York, McGraw-Hill Book Company, Inc., 1938.

4. Thornthwaite, C: W., Atlas of Climatic Types in the United States, 1900-1939. Washington, D. C., U. S. Department of Agriculture, 1941, Miscellaneous Publication 421.

5. Society of American Foresters, Committee on Forest Types, Forest Cover Types of the Eastern United States. 3rd. ed. rev., Washington, D. C., 1940.

6. Schantz, H. L., and Zon, R., Natural vegetation in Atlas of American Agriculture, Washington, D. C., U. S. Dept. of Agriculture, 1936.

7. Klages, K. H. W., Ecological Crop Geography. New York, The Macmillan Company, 1942.

8. U. S. Bureau of the Census, County Data Book. A supplement to the Statistical Abstract of the United States. Washington, D. C., 1947.

9. Longwell, C. R., Knopf, A., and Flint, R. F., Textbook of Geology. Part I. Physical Geology. New York, John Wiley and Sons, Inc., 1932.

10. Marbut, C. F., Soils of the United States in Atlas of American Agriculture, Washington, D. C., U. S. Department of Agriculture, 1936.

11. Baldwin, M., Kellog, C. E., and Thorp, J., Soil classification in Yearbook of Agriculture: Soils and Men, Washington, D. C., U. S. Department of Agriculture, 1938, pp. 979-1001.

12. Israel, H. L., and Sones, M., Sarcoidosis. Am. Pract. \& Digest Treatment, 1952, 3, 18.

13. Hamilton, J., Personal communication.

14. Rakich, J. H., Personal communication.

15. Carr, D. T., and Gage, R. P., The geographic distribution of sarcoidosis. Am. Rev. Tuberc., 1954, 70, 899.

16. Longcope, W. T., and Freiman, D. G., A study of sarcoidosis: Based on a combined investigation of 160 cases including 30 autopsies from The Johns Hopkins Hospital and Massachusetts General Hospital. Medicine, 1952, 31, 1.

17. Lomholt, S., Douze cas de Sarcoïdes de Boeck Traités à l'antiléprol. Bull. Soc. Franç. de dermat. et syph., 1934, 41.1354. 
18. Whitehead, H. G., Sarcoidosis: Manifestations of tuberculosis without allergy; studies on possible etiological relationship of acid-fast chromogen isolated from two cases. Bull. Am. Acad. Tuberc. Physicians, 1940, 4, 117.

19. Cone, R. B., A review of Boeck's sarcoid with analysis of twelve cases occurring in children. J. Pediat., 1948, 32, 629.

20. Refvem, O., I. Chronic granulomas in the alimentary tract caused by minute mineral particles. II. "Boeck's Disease" and occurrence of minute mineral particles (Preliminary Report). Acta Pathologica, 1948, XXV, 107.

21. Love, A. G., and Davenport, C. B., Immunity of citybred recruits. Arch. Int. Med., 1919, 24, 129.

22. Leitner, S. I., Der Morbus Besnier-Boeck-Schaumann; Chronische Epitheloidzellige Reticuloendotheliose oder Granulomatose. 2. Erweiterte Aufl., Basel, Benno Schwabe \& Co., 1949.

23. Schönholzer, G., Morbus Besnier-Boeck-Schaumann und Armeedurch-Leuchtung. Schweiz. med. Wchnschr., 1947, 77, 585.

24. Lewis, J. H., The Biology of the Negro. Chicago, Univ. of Chicago Press, 1942.

25. Augustine, D. L., and Smillie, W. G., The relation of the type of soils of Alabama to the distribution of hookworm disease. Am. J. Hyg., 1926, 6, March Suppl., 36.

26. Chandler, A. C., Hookworm Disease; Its Distribution, Biology, Epidemiology, Pathology, Diagnosis, Treatment and Control. New York, The Macmillan Co., 1929.

27. Grayston, J. T., and Furcolow, M. L., The occurrence of histoplasmosis in epidemics-epidemiological studies. Am. J. Pub. Health, 1953 43, 665.

28. Smith, C. E., Epidemiology of acute coccidioidomycosis with erythema nodosum. ("San Joaquin" or "Valley Fever"). Am. J. Pub. Health, 1940, 30, 600.

29. Smith, C. E., Beard, R. R., Rosenberger, H. G., and Whiting, E. G., Effect of season and dust control on coccidioidomycosis. J. A. M. A., 1946, 132, 833.

30. Dyer, R. E., Rumreich, A., and Badger, L. F., Typhus fever. A virus of the typhus type derived from fleas collected from wild rats. Pub. Health Rep., 1931, 46, 334.
31. Barber, M. A., Komp, W. H. W., and Hayne, T. B., The susceptibility to malaria parasites and the relation to the transmission of malaria of the species of Anopheles common in the Southern United States. Pub. Health Rep., 1927, 42, 2487.

32. Dyer, R. E., The control of typhus fever. Am. J. Trop. Med., 1941, 21, 163.

33. Eskey, C. R., Relation of reported cases of typhus fever to location, temperature, and precipitation. Pub. Health Rep., 1948, 63, 941.

34. Malaria Control on Impounded Water. Federal Security Agency, U. S. Public Health Service, and Tennessee Valley Authority, Health and Safety Department, Washington, D. C., U. S. Government Printing Office, 1947.

35. Davis, D. J., and Pittman, M., Acute conjunctivitis in the South. CDC Bulletin, 1950 (April), 9, 18.

36. Dow, R. P., The eye gnat problem. CDC Bulletin, 1950 (April), 9, 20.

37. Ayres, W. W., Ober, W. B., and Hamilton, P. K., Post-traumatic subcutaneous granuloma associated with a crystalline material. Am. J. Path., 1951, 27, 303.

38. German, W. M., Lupoid-sarcoid reaction induced by foreign body (Silica). Am. J. Clin. Path., 1940, 10, 245.

39. King, C. O., Posttraumatic sarcoid-like lesions. South. M. J., 1946, 39, 122.

40. Gardner, L. U., The similarity of the lesions produced by silica and by the tubercle bacillus. Am. J. Path., 1937, 13, 13.

41. Hardy, H. L., and Tabershaw, I. R., Delayed chemical pneumonitis occurring in workers exposed to beryllium compounds. J. Indust. Hyg. \& Toxicol., 1946, 28, 197.

42. Vorwald, A. J., Pneumoconiosis; Beryllium, Bauxite Fumes, Compensation. New York, Paul B. Hoeber, Inc., 1950.

43. Freiman, D. G., Sarcoidosis. New England J. Med., 1948, 239, 664-671, 709-716, 743-749.

44. Dutra, F. R., Cholak, J., and Hubbard, D. M., The value of beryllium determinations in the diagnosis of berylliosis. Am. J. Clin. Path., 1949, 19, 229.

45. Hodge, H. C., Toribara, T. Y., and Steadman, L. T., Personal communication.

46. Cholak, I., and Hubbard, D. M., Personal communication. 